\title{
Migration of Students- A Comparative Study among Different Countries of the World
}

\author{
Harkirat Kaur, Dr. Rashmi Aggarwal
}

Pehowa, Haryana, India

\begin{abstract}
How to cite this paper: Harkirat Kaur | Dr. Rashmi Aggarwal "Migration of Students- A Comparative Study among Different Countries of the World" Published in International Journal of Trend in Scientific Research and Development (ijtsrd), ISSN: 24566470, Volume-3 | Issue-4, June 2019, pp.256-261, URL: https://www.ijtsrd.c om/papers/ijtsrd23 594.pdf



Copyright (c) 2019 by author(s) and International Journal of Trend in Scientific Research and Development Journal. This is an Open Access article distributed under the terms of the Creative Commons

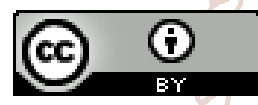
Attribution License (CC BY 4.0) (http://creativecommons.org/licenses/ by $/ 4.0$ )

This phenomenon leads to "Brain-Drain". Despite students, the Professional people who were educated from India wants to do job overseas and settle there, mainly in the fast moving countries like US, Australia, Canada etc.

The number of student migration from India is increasing rapidly. The main benefit of studying abroad is that students get the field in which they are actually interested in and in which they want their specialization to be, which may they don't get in their home country. The degree which they obtained from the host country is worth when it comes to finding a job in the foreign country or in any other nation. The other benefit of that degree is that the host country allows the student to live there even after completing their education and treat them fairly when they apply for the residential purpose.

Due to highly increased competition, countries required highly skilled migrants and to attract more and more international students, the countries are changing their policies. They start giving easy visas, work while studying, and job after studies etc. These are some of the ways that the foreign countries are doing to attract the international students. There are some factors like quality education, employment, standard of living etc. leads to student mobility. One of the main factor is poor job opportunities in the domestic nation and getting the jobs in the host country leads to high cross border mobility.
According to UIS (UNESCO Institute for Statistics), the international student migration was about 1.1 million in 1980 and after a decade reached to million 1.3 but a decade before now it was million 3.4. Countries which are popular among international students are Canada, Australia, US, UK, Germany etc.

\section{Scope of this paper}

In the end, this paper will help to determine the various factors and sources that help the students to keep into consideration while going to some foreign country and this will also help the global universities to make their policies by keeping in consideration these factors.

Objective

$>$ To study the various factors which influence the students to go abroad

$>$ To examine the proportion of students who are getting education in foreign countries

$>$ To examine the total number of foreign students coming to India

\section{Hypothesis}

$>$ There is no relationship between the factors and the students going abroad ( $\mathrm{HO}$ )

$>$ There is a direct relationship between the educational opportunities and the increase in cross border mobility (H1) 


\section{Research Design}

The data is taken from Secondary sources. The data is taken from many authenticated websites and organizations like "The Ministry of Tourism, UNESCO, Ministry of External Affairs, and All India Survey on Higher Education" etc. This research paper is also written with the help of many other research papers which are written by professionals.

\section{Review of Literature}

This paper has 2 sections:

$>$ The first section will show the number of student migration from India to other countries and the various factors which influence them.

$>$ The second part will show the number of foreign students coming to India and studying various courses.

\section{Part 1}

Everyone has dream of going to foreign countries may be for the study purpose, job purpose or just for roaming and enjoying. From the past years, the trend of going to abroad has been increased rapidly like never before. According to "The Ministry of Tourism", the total number of departures of Indian nationals is increasing every year from 2000-2017. It includes every individual whether he/she is student going to study abroad, professional people going for job, people going for vacations, etc. The data showing the number of Indian Nationals which are going overseas from India from 20002017 (in millions) is given below:

Table 1 Number of Indian Nationals' Departures from India, 2000-2017 (in Millions)

\begin{tabular}{|l|c|}
\hline Year & Indian Nationals Departures(in millions) \\
\hline 2000 & 4.42 \\
\hline 2001 & 4.56 \\
\hline 2002 & 4.94 \\
\hline 2003 & 5.35 \\
\hline 2004 & 6.21 \\
\hline 2005 & 7.18 \\
\hline 2006 & 8.34 \\
\hline 2007 & 9.78 \\
\hline 2008 & 10.87 \\
\hline 2009 & 11.07 \\
\hline 2010 & 12.99 \\
\hline 2011 & 13.99 \\
\hline 2012 & 14.92 \\
\hline 2013 & 16.63 \\
\hline 2014 & 18.33 \\
\hline 2015 & 20.38 \\
\hline 2016 & 21.87 \\
\hline 2017 & 23.94 \\
\hline
\end{tabular}

Source: The Ministry of Tourism

The table number 1 shows the data from year 2000-2017 taken from the report of "The Ministry of Tourism" which is the authenticated report and which shows that with the increasing time, the number of pupils going abroad are also increasing, which shows an upward trend. This led to increase in the GDP's of the other countries where the pupils are going.
Figure 1 Indian National Departures (in millions) Indian Nationals Departures(in millions)



Figure 1 shows the number of years (2000-2017) on the Horizontal Axis and the number of Indian Nationals Departures (in millions) on the Vertical Axis. This shows the increasing slope indicating an upward trend. This graph shows that with the increasing years, the trend of going abroad among people is also increasing. In the year 2000, about 4.42 million people were going abroad and in the year 2017 , it has increased to 23.94 million people, which is 6 times greater than year 2000 .

\section{Factors}

Different studies have proven that family influence is the major factor which encourages the student to study abroad. (Quintal, Shank and Taylor 2005; Soutar and Mazzarol 2002; Pimpa 2003) examine that family influence is the biggest factor which led the student to study overseas. The mindset of the family members affects the students' behavior (Etzel and Bearden 1982). The recommendation of the family influences the student to decide the host country and institution (Bourke 2000; Baron, Harris and Moogan 1999). A paper by Pope, Aki-Knight and Shanka (2009) examine that $37 \%$ of the International Under-Graduate students says that friends and parents are their main source of data for Australia and United Kingdom.

If there are friends studying in different countries in different institutions, they also encourage others for cross border education. The sources of family and friends are easily reliable and trusted because they are not profit oriented.

Another factor is the financial situation of the student to go abroad and chooses specific university or college (Shank 2005; Reed, Lahey and Downey 1984). Financial situation is the most important factor (Gorman 1974). (Pitlik, Vaugh and Hansotia 1978) they ranked the cost of the universities at $10^{\text {th }}$ place in the list of factors. However, other researchers like (Bourke 2000, Conard and Conard 2000) take it as a most important factor while taking a decision to study overseas.

Beside the above factors, students can also gather information themselves via: internet, newspapers, reviews, educational agents etc. Despite having so much sources for getting information, the researcher like (James 1999) examine that international students have limited information to decide that which course they have to choose for their career. On internet, there is limited information about the teaching and study pattern of the universities. (Murphy and Groms 2003) indicated that there must be sufficient information on internet so that students can take correct decisions about host countries and the various global universities. 
There are various reasons that why the demand for international students are higher. The first and foremost reason is that higher the international students, higher the financial resources in the host country and higher the funds are provided for the smooth functioning of the private institutions. (Khadria, 2001) indicated that they increase the standards of performance of the Universities, which attracts the foreign students as well as it also mark positive effect on the global ranking. The increasing number of International students also increases the FDI's (Foreign Direct Investment) and GDP (Gross Domestic Product) of the country, impacting the country to grow and develop more.
India is both a host country as well as the highest student forward country to other nations. The top 5 countries where the Indian students prefer to go are: UK, Canada, Australia, USA and New Zealand. These countries are on the top most lists of the Indian students' while taking a decision to study abroad. Like India, there are many other nations which are leading at sending students internationally. According to UNESCO Institute for Statistics, China is on the top in terms of sending their students internationally and then followed by India. Table number 2 shows the data taken from "UNESCO Institute for Statistics" showing the total outbound internationally mobile tertiary students studying abroad of some main nations from the year 2012-2017.

Table 2 Total number of internationally mobile tertiary students studying abroad

\begin{tabular}{|c|c|c|c|c|c|c|}
\hline Indicator & \multicolumn{7}{|c|}{ Total mobile tertiary students studying abroad } \\
\hline & \multicolumn{7}{|c|}{ Year } \\
\hline Country & 2012 & 2013 & 2014 & 2015 & 2016 & 2017 \\
\hline Australia & 11137 & 11987 & 12369 & 12138 & 12783 & 12713 \\
\hline Canada & 45844 & 46546 & 47337 & 49704 & 50268 & 50222 \\
\hline U.S & 64162 & 67023 & 68652 & 70553 & 72690 & 72830 \\
\hline France & 64196 & 76576 & 82057 & 86690 & 90543 & 90717 \\
\hline Germany & 118157 & 120150 & 118494 & 117104 & 119088 & 119021 \\
\hline India & 191779 & 190358 & 215611 & 256636 & 301406 & 305970 \\
\hline China & 698401 & 719065 & 770516 & 819524 & 866072 & 869387 \\
\hline
\end{tabular}

\section{Source: UNESCO Institute for Statistics}

The above table shows the total number of international students who are studying abroad of 7 countries from the year 2012 2017. The bar graph of the same is plotted below:

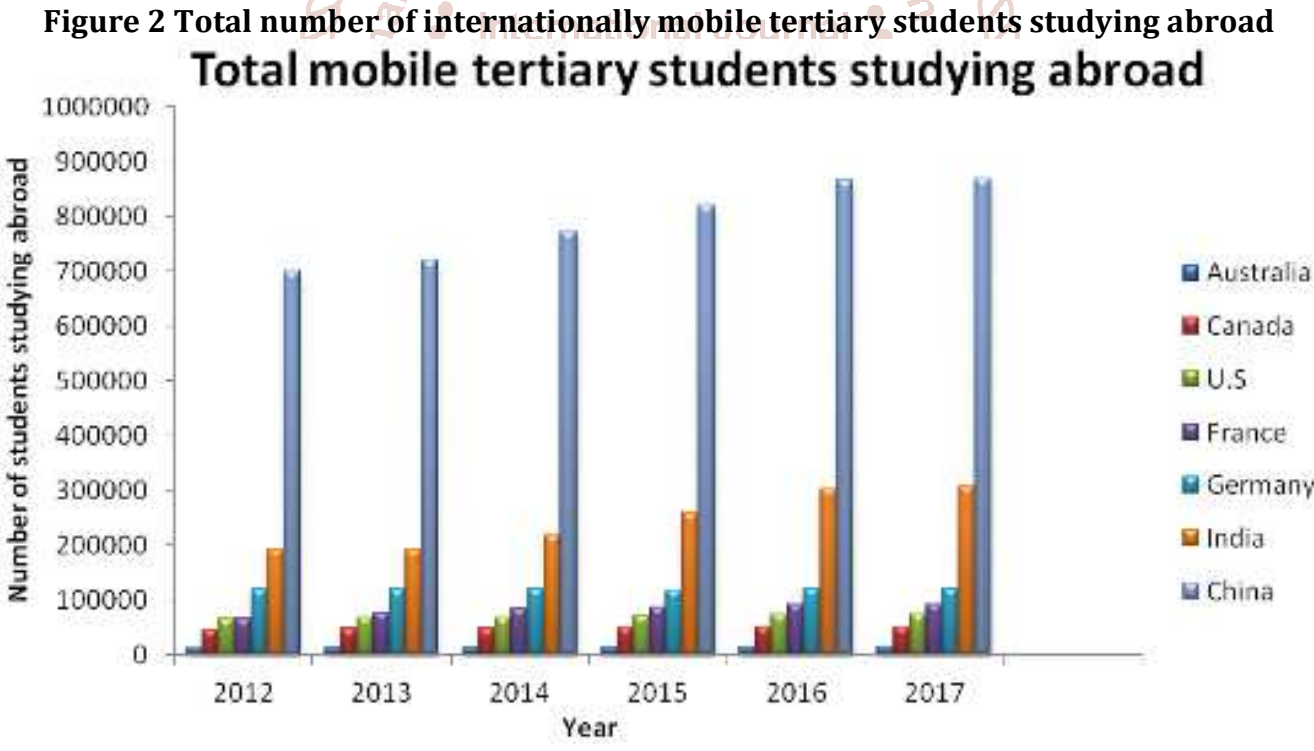

The bar graph shows Year on the Horizontal Axis and number of students studying abroad on the vertical axis. The data shows that how many students are studying abroad from different countries. It shows the data of 7 major countries. From this data, it can be said that China is on the top most having highe3st number of students studying abroad and it has been continuously increasing from the past years and then followed by India, Germany, France, US, Canada and Australia.

If the segregation is to be made that how many Indian students are studying in different countries, then the top most is in United States of America and then followed by Canada. The data to show this has been stated below which is taken from "The Ministry of External Affairs"
Table 3 Number of Indian Students studying in different countries (2018)

\begin{tabular}{|c|c|}
\hline Countries & $\begin{array}{c}\text { Number of Indian } \\
\text { Students studying }\end{array}$ \\
\hline US & 211,703 \\
\hline Canada & 124,000 \\
\hline Australia & 87,115 \\
\hline Saudi Arabia & 70,800 \\
\hline United Arab Emirates & 50,000 \\
\hline New Zealand & 30,000 \\
\hline China & 18,171 \\
\hline UK & 16,550 \\
\hline Germany & 15,308 \\
\hline
\end{tabular}

Source: The Ministry of External Affairs 
The table number 3 shows the data of students studying in 9 different countries. The data is taken from Ministry of External Affairs of 2018. About 600,000 Indian students are studying in different areas of the whole world. This data shows that USA is having highest number of Indian students studying there i.e. 211,703 and then followed by Canada i.e. 124,000 . The least number of Indian students are in UK. All thanks to these countries for changing their immigration policies for the international student migration and making the rules and policies which attracts the international students to study there. The pie chart of the same data is shown in Figure 3 in terms of percentage.

Figure 3 Number of Indian Students studying in different countries

\section{Number of Indian Students studying} in different countries

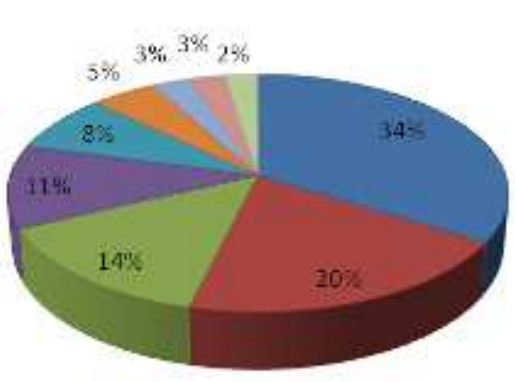

aUS

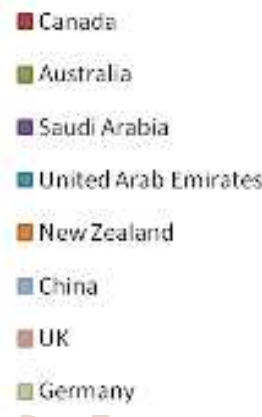

This pie chart shows the different countries in different colors and the percentage of Indian students which are studying there. The cost of education in Canada is less than the other countries. It also gives scholarships for the post graduation courses than the graduation courses. From this data, it can be said that there are 3 most preferred countries by the Indian students (USA, Canada, and Australia). This also means that there are increasing middle income families, who are able to send their children abroad in foreign universities.

\section{Part 2}

India is also a preferable country for the international students. India has the world's largest education system. It has more than 350 Universities and 16000 colleges. The Indian government has also made some changes in the policies to encourage and help the international students from the developing countries to study here. The international students coming to India increases the GDP and FDI's of India. According to Ministry of External Affairs, the proportion of international students from the past years is decreasing. The data related to this is shown in table number 4 taken from "The Ministry of External Affairs".

Table 4 Number of foreign students came to India

\begin{tabular}{|c|c|}
\hline Year & No. of foreign students came to India \\
\hline 2014 & 65,602 \\
\hline 2015 & 74,061 \\
\hline 2016 & 72,542 \\
\hline 2017 & 69,322 \\
\hline
\end{tabular}

Source: The Ministry of External Affairs

In table number 4, the data is shown of 4 years (2014-2017). It shows that the number of foreign students in the year 2015 increases rapidly compared to 2014 but then starts declining and currently there are approx 50,000 international students in India. The government has to do something in context to attract the foreign students. It is more clear from the below bar graph.

\section{Figure 4 \\ No. of foreign students came to India}



There is sharp rise in the number of foreign scholar from 2014 to 2015 but afterwards, there is a declining trend. There is approx 5000 decrease in the figures of international students from year 2015 to 2017. If the measures were not taken, then these numbers will continuously decline which leads to less inflow of Foreign Direct Investment.

Foreign students from 10 different countries:

The foreign students come from 162 different countries from the world to India for study purpose. The highest number of international students comes from Nepal and fewer students are from Iran as shown in figure 5.

\section{clentific $\quad$ Figure 5 \\ Foreign student disribution in top 10 countries
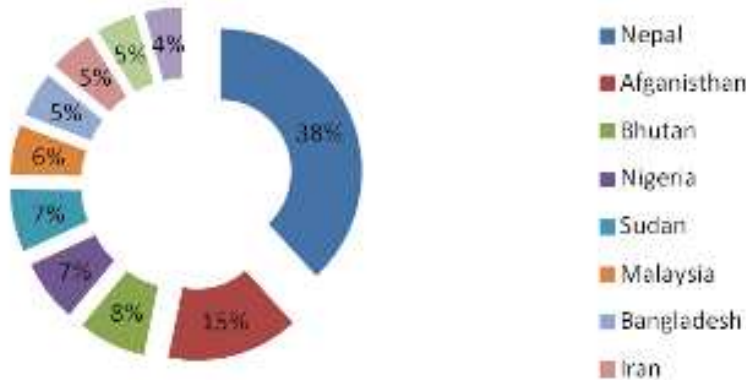

Source: All India Survey on Higher Education (201617)

This data comprises of $62 \%$ of the number of international students coming from top 10 countries studying in India and the rest $38 \%$ comes from different 152 countries. The highest number of students came from Nepal i.e. 38\% then followed by Afghanistan (15\%). The least number of students come from Iran i.e. $4 \%$.

\section{State-wise distribution of foreign students:}

There are 26 states in India. The number of foreign students is highly differing from state to state. According to "All India Survey on Higher Education" there are approx 50,000 foreign students in India and the highest number of foreign students is in Karnataka comprising 13,050 international students whereas state like Mizoram has only 7 international students. The figure number 6 shows the data of 10 different states which are having high number of international. 


\section{No. of foreign Students}

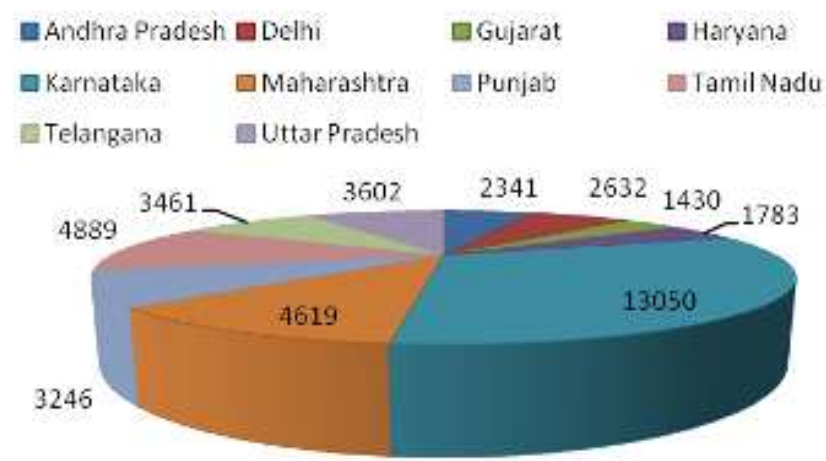

Source: All India Survey on Higher Education (201617)

It is crystal clear from figure 6 that Karnataka is the top most preference of international students (13050). Beside this, Tamil Nadu is on the second place (4889) then Maharashtra (4619), UP (3602), Telangana (3461), Punjab (3246), Delhi (2632), Andhra Pradesh (2341), Haryana (1783), Gujarat (1430).

\section{"Study in India" Scheme:}

The government announced a plan to attract about 2 lakh international students to India which is 4 times greater than the current number of students. This scheme is launched by 4 ministries: human resource development, home, commerce and external affairs. Easy visas and fee waiver has been provided under this scheme to international students from Africa and Asia.

The Union Human Resource Development Minister said that there are many complain about strict rules in the Indian higher education and now the government is making many efforts to liberalize it. India can become a country where the foreign students can afford their fees and they are opening many top universities for them.

This scheme will open gates for foreign students and provide them prominent education. India is targeting students from South, West Asia, Africa and South-East. Initially, 30 countries and 160 colleges and universities are targeted to start the plan. In order to make this plan more attractive, government and institutions offer fee waiver to $53 \%$ of foreign students. The students from that

30 countries will apply online to 160 colleges. This scheme will bring together students of different cultures in the Indian Universities.

\section{Conclusion:}

International education has now become trend in most of the countries like US, Australia, Canada etc. They contribute a lot to the host country's economy and generate lots of work. The foreign countries should also take into consideration the students perspectives. The countries and institutions should give fee waiver to the foreign students, so that they can afford the fees. The result of this paper shows that family is the main source of information and they influence a lot to student regarding where they have to study. This paper also shows that how many students of India are studying abroad and how many international students are studying in India in various states and how many students are coming from which country. To encourage more foreign scholars, the universities should built a successful brand name and design their programs in such a manner that it does not cost much to the student and should be completed in a reasonable time.

\section{Limitations of the Study}

This paper does not include the major hurdles that students face while taking a decision regarding study outer world. The future research can be done on the males and females studying abroad and the number of international students segregated as males and females studying in India.

\section{References}

[1] Hercog Metka, Van de Laar Mindel (2016), Motivations and constraints of Moving abroad for Indian students: International Migration and Integration.

[2] Kakkad Poonam, Nair T.P. Madhu (2015), A study on the factors influencing students decision to study abroad, Volume 7 Issue- 2.

[3] Rajan S. Irudaya, Wadhawan Neha (2013), Future Diasporas? International student migration from India to UK

[4] King Russell, Sondhi Gunjan (2016), Gendering International Student Migration: A Comparison of UK and Indian Students' Motivations and Experiences of Studying Abroad, Working Paper No. 84

[5] IOM (2008) World Migration 2008. Geneva: International Organization for Migration.

[6] UNESCO Institute for Statistics (2012) New Patterns in student mobility in the Southern Africa Development Community

[7] Hawthorn Lesleyanne (2006) Labour Market Outcomes for Migrant Professionals: Canada and Australia Compared

[8] Shanka, T., Quintal, V., \& Taylor, R. (2005) Factors Influencing International Students' Choice of an Education Destination- A Correspondence Analysis, Journal of Marketing for Higher Education, 15(2), 3146

[9] Moogan, Y. J., Baron, S., and Harris, K. (1999) DecisionMaking Behavior of Potential Higher Education Students. Higher Education Quarterly, 53(3): 211-228

[10] Mazzarol, T, \& Soutar, G. (2002) Push-pull factors influencing international students' destination choice The International Journal of Educational Management, 16 (2), 82-90

[11] Yang, R. (2003) Globalization and higher education, International Review of Higher Education, 49(3-4): 269-291

[12] King, R. and Ruiz-Gelices, E. (2003) International student migration and the European 'year abroad': effects on European identity and subsequent migration behaviour, International Journal of Population Geography, 9(3): 229-252.

\section{Websites}

[1] https://qph.fs.quoracdn.net/main-qimg75a1995e1d0ec85edbfaa32c1077b11d

[2] http://aishe.nic.in/aishe/viewDocument.action?docume ntId $=239$ 
International Journal of Trend in Scientific Research and Development (IJTSRD) @ www.ijtsrd.com eISSN: 2456-6470

[3] https://i1.wp.com/factly.in/wpcontent/uploads//2017/08/Indians-students-studyingabroad-top-countries.jpg?resize $=702 \% 2 \mathrm{C} 418 \&$ ssl $=1$

[4] http://tourism.gov.in/sites/default/files/FTA/Press\%2 0Note\%20FTAs\%20Nov\%2018.pdf

[5] https://www.statista.com/statistics/878831/indianumber-of-international-students-in-higher-education/
[6] https://wenr.wes.org/2017/08/india-mappingstudent-mobility-from-the-worlds-number-2-sender

[7] https://chaibisket.com/indian-students-abroad/

[8] https://www.careerindia.com/study-abroad/sevppublishes-2017-international-student-data-2-lakhindian-students-studying-in-usa-024032.html

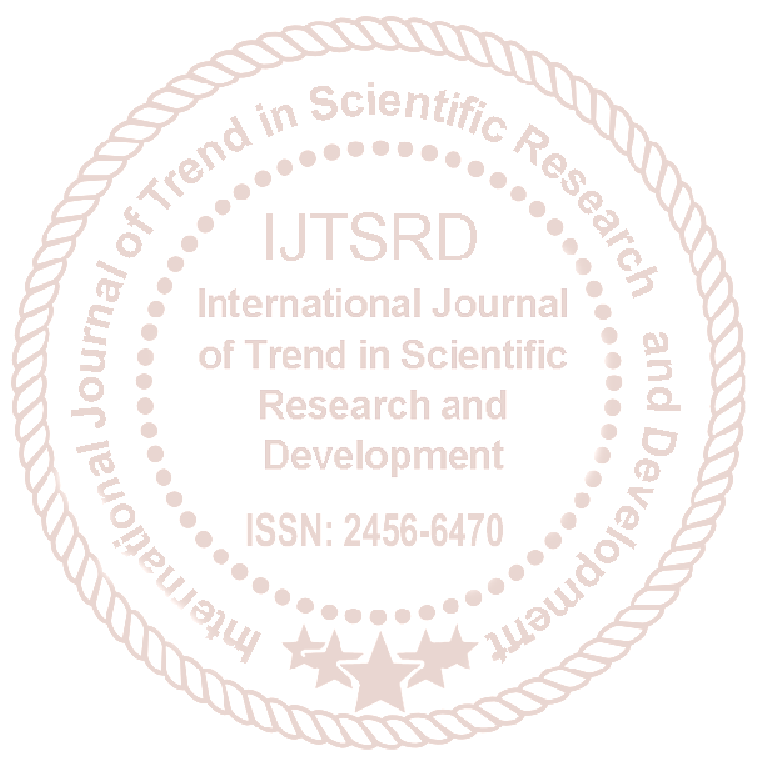

